\title{
Utilization of the thermohydric stress in the psamosols area in Southern Oltenia through the cowpea culture
}

\author{
Reta Draghici $^{1 *}$, Iulian Draghici ${ }^{1}$, Aurelia Diaconu ${ }^{1}$, Mihaela Croitoru ${ }^{1}$, \\ Alina Nicoleta Paraschiv ${ }^{1}$, Milica Dima $^{1}$ and Mircea Constantinescu ${ }^{1}$ \\ ${ }^{1}$ Research Development Station for Plant Culture on Sands Dabuleni, 207170, Călărași, Dolj, \\ Romania
}

\begin{abstract}
The area of psamosols in southern Oltenia is characterized by thermohydraulic stress, accentuated by the thermal resources recorded and by the poor hydrophysical properties of the soil. Higher capitalization of these lands has been an important concern both in the world and in our country, and the choice of plant species with increased drought resistance and low water consumption is a measure to counteract the negative effects of the drought. The humidity analysis of a psamosol, on the $0-125 \mathrm{~cm}$ profile, indicates a momentary supply of reduced water and a water deficit compared to the field capacity of $-34.4 \ldots-65.5 \mathrm{~m}^{3} /$ ha. In order to obtain economic results on these soils, it is necessary to cultivate low-water plants, such as a cowpea (Vigna unguiculata L. Walp) that consumes about $4160 \mathrm{~m}^{3} / \mathrm{ha}$, compared to soybeans that have almost double consumption. The results obtained in 4 genotypes of cowpea highlight the daily average values of the plant's foliar sweating, in the blooming phase, ranging between $4.05-5.23 \mathrm{mmol}_{2} \mathrm{O} / \mathrm{m}^{2} / \mathrm{s}$, which correlated negatively with the level of grain production.
\end{abstract}

\section{Introduction}

Cowpea (Vigna unguiculata (L.) Walp), is a drought-resistant plant, with little pretentions to soil conditions and an important source of protein for climatic-deprived areas [7, 10]. In most of the crop areas, the plant ensures its water needs mostly from precipitation and less from irrigation, being more tolerant to drought compared to soybeans [11]. In some tropical areas of developing countries, such as the areas of Sahelian Africa and the northeast region of Brazil, legumes are cultivated only during the rainy season, and drought stress is the most important threat for the production of biomass for many small farmers $[15,16]$. For people in these regions, cowpea is an important source of protein.

In Central Africa and West Africa, 64\% of the total cultivated area is the culture of cowpea. In the tropical and subtropical regions of the sub-Saharan African region, cowpea is cultivated for biomass and grains, being an important resource for the economy. According to the Food and Agriculture Organisation (FAO), cowpea is cultivated on at least 12.5 million hectares [2]. Cowpea is a specie with reduced requirements to the soil, and from this point of view areas with sand and sandy soils provide favourable conditions for the growth and development of the plant. As a leguminous plant, the cowpea forms on the 
roots numerous nodozities, which develops the bacterium that secures atmospheric nitrogen $[5]$.

The nitrogen in the atmosphere that is biologically fixed by leguminous plants, compared to mineral nitrogen, has advantages, because fossil energy is not consumed for its production and is environmentally friendly. The research carried out in 1988 by Gheorghe D. and Şuteu G.E., quoted by Draghici Reta [13], by using the isotope nitrogen to fertilize the cowpea, shows that the cowpea can synthesize with the help of symbiotic bacteria of the genus Rhizobium cca. $78,2-80,6 \%$ of the nitrogen required for production. From the chemical fertiliser applied, the plant uses only $0,53-2.71 \%$, with a very low coefficient of use of the fertiliser (3.98-4.56\%), due to its leaching in the soil.

\section{Methodology}

The research was carried out at Research Development Station for Plant Culture on Sands Dăbuleni (RDSPCS), and aimed at the response of the cowpea plant to the thermic and hydric stress in southern Oltenia. The study was conducted on a low natural fertility psamosol, characterized by a reduced supply of organic carbon $(0.28-0.45 \%)$ nitrogen (0,039-0.08\%), a medium-sized supply of phosphorus (21.8-30.5 ppm) and potassium (75$91,5 \mathrm{ppm})$. The $\mathrm{PH}$ of the soil on which the experience was placed showed values of 4.18 6.25 , which shows a strong acidic to moderately acidic reaction.

The Analysis of soil fertility was carried out by harvesting of soil samples which were recorded and conditioned in the laboratory, from which the following determinations were carried out:

- Total Nitrogen - Kjeldahl method;

- Extractable phosphorus (P-AL) - Egner - Riem Domingo method, whereby phosphates are extracted from the soil sample with a solution of acetate - ammonium lactate at $\mathrm{pH}-5.75$, and the extracted phosphate anion is determined as-blue molybdenum;

- Replaceable potassium (K-AL) - Egner - Riem Domingo method whereby the hydrogen and ammonium ions of the extraction solution replace the potassium ions in the changeable form of the soil sample, which are thus passed in the solution. The Dosing of potassium in the solution thus obtained is made by flame emission photometry.

- Organic carbon - wet oxidation method and titanium dosing (after Walkley - Blak in the Gogoaşă modification);

- Soil $\mathrm{pH}$, potentiometric method

To establish the irrigation regime of the cowpea, soil samples were harvested monthly on the depth of $0-125 \mathrm{~cm}$ and the soil humidity was determined, using the gravimetric method, by evaporation of water physically linked to the soil at $105^{\circ} \mathrm{C}$, with the help of the oven. The following hydrophysic indices of the soil were calculated: the momentous supply of water, the reserve against the wilting coefficient, the deficit to the field capacity and the water supply in the soil, to which the irrigation was applied.

In this respect, the following calculation formulas were used:

- Water momentan supply $=(100 * \mathrm{H} * \mathrm{Da} * \mathrm{~W})$, where,:

$$
\begin{aligned}
& \mathrm{W}=\text { soil humidity }(\%) \\
& \mathrm{H}=\text { depth of soil }(\mathrm{m}) \\
& \mathrm{Da}=\text { apparent soil Density }
\end{aligned}
$$

- Wilting coefficient $(\mathrm{CO})=100 * \mathrm{H} * \mathrm{Da} * \mathrm{CO}$

- $\quad$ Field Capacity $(\mathrm{CC})=100 * \mathrm{H} * \mathrm{Da} * \mathrm{CC}$

- Minimum ceiling of water (30\% of the active humidity range, on the depth of 50 $\mathrm{cm})=\mathrm{CO}+1 / 3(\mathrm{CC}-\mathrm{CO})$

- Water Reserve = momental Supply-Minimum cap

- $\quad$ Water Deficit = Momental supply - Field Capacity

Hydrophysic Indices of the sandy soil: 


$$
\begin{aligned}
& \mathrm{Da}=1.38-1.46 \mathrm{~g} / \mathrm{cm}^{3} \text { (depending on the depth of the soil) } \\
& \mathrm{CO}=2 ; \mathrm{CC}=9
\end{aligned}
$$

Experience aimed at the morpho-physiological behavior of 4 cowpeas genotypes (Jiana, Aura 26, Ofelia, Doljana) cultivated in a 3-year rotation: cowpea-rye-sorghum. The Jiana variety is a late variety, with a 103 day vegetation period, reddish brown bean and a crude protein content of about $21.8 \%$. This variety develops a rich vegetative mass, being recommended as a green fertilizer for sands, or as feed for animal feed. The other varieties of cowpea, respectively, Aura 26 with a vegetative period of 91 days and grain white and hil brown, Ofelia with a vegetative period of 95 days and grain white and hil black and Doljana, with a growing period of 92 days and white grain are especially recommended for human food in the form of beans with a high protein content in grains of 22.2-22.9\% or green pods due to the high vitamin C content (over $35 \mathrm{mg} / 100 \mathrm{~g}$ of fresh substance). During the vegetation of the cowpea varieties, they were carried out the determinations of biometrics, physiology (dry substance, water formes in the plant, photosynthesis, transpiration) and variety-based productivity were performed.

The forms of water were determined gravimetrically with the help of the oven, and the photosynthesis rate, the transpiration rate and the stomatic conductance were performed with the help of the device: LC Pro +.

\section{Rezults and discusions}

The climatic conditions recorded in the year 2018 (Table 1) were favourable to the growth and development of the cowpeas plants, with an average air temperature recorded during the plant vegetation period (May-August) of $22.97{ }^{\circ} \mathrm{C}$, with a deviation in addition to $2{ }^{\circ} \mathrm{C}$, compared to the same multiannual period. The thermal regime of the area, created by the accumulation in the air of approx $2825.31{ }^{\circ} \mathrm{C}$, was favorable for the normal conduct of biological and physiological processes in the culture of cowpea, the literature mentioning a necessity of approx $2000{ }^{\circ} \mathrm{C}$ [3]. Rainfall during this period exceeded the multiannual average by $262.21 \mathrm{~mm}$, but were unevenly distributed to the requirements of the cowpea plant.

Table 1. Maximum Air $\left({ }^{0} \mathrm{C}\right)$ and precipitation $(\mathrm{mm})$ in the period April-September 2018, recorded at Dabuleni RDSPCS weather Station

\begin{tabular}{|l|c|c|c|c|c|c|}
\hline Month/decade & April & May & June & July & August & $\begin{array}{c}\text { May - } \\
\text { August }\end{array}$ \\
\hline $\begin{array}{l}\text { Monthly average monthly } \\
\text { Temperature }\left({ }^{\circ} \mathrm{C}\right)\end{array}$ & 17.8 & 20.7 & 22.5 & 23.6 & 25.1 & 22.97 \\
\hline $\begin{array}{l}\text { Average monthly multi- } \\
\text { annual temperature }\left({ }^{0} \mathrm{C}\right) \\
(1956-2017)\end{array}$ & 11.8 & 16.8 & 21.6 & 23.1 & 22.4 & 20.97 \\
\hline $\begin{array}{l}\text { Temperature deviation } \\
\text { from multi-annual } \\
\text { average }\left({ }^{0} \mathrm{C}\right)\end{array}$ & 6 & 3.9 & 0.9 & 0.5 & 2.7 & 2 \\
\hline Rainfall (mm) & 17 & 106.6 & 195.2 & 148.7 & 30 & 480.5 \\
\hline $\begin{array}{l}\text { Sum of multiannual } \\
\text { monthly rainfall (mm) } \\
(1956-2017)\end{array}$ & 47.52 & 62.39 & 68.46 & 54.24 & 33.2 & 218.29 \\
\hline $\begin{array}{l}\text { Rainfall deviation from } \\
\text { multi-annual average (mm) }\end{array}$ & -30.52 & 44.21 & 126.74 & 94.46 & -3.2 & 262.21 \\
\hline
\end{tabular}


Thus, from the analysis of the daily distribution of rainfall (Figure 1), it is noted that between 10 April and 10 May there were $12.6 \mathrm{~mm}$, insufficient quantity for a uniform emergence of plants, being necessary to complement the water deficit with irrigation. The 2nd water shortage for cowpea was recorded in the flowering period of the plant, which coincided with the last decade of June. During the period of the occurrence of floralsflowering (16-25 June) were recorded just $14.4 \mathrm{~mm}$ precipitation, insufficient amount for the conduct of the physiological processes of the plant, and it was also necessary to irrigate the culture.

The research results obtained in the sandy soils in southern Oltenia show that the cowpea has high requirements for the water, for the imbibition water and germination of the seeds of cowpeas, and if in this interval the edaphic drought occurs in the superficial layer $(0-20 \mathrm{~cm})$ an emergence watering is required with a reduced watering quota $\left(150-200 \mathrm{~m}^{3}\right.$ water/ha) [6]. In the first 30-40 days the cowpea has a slow growth rate, during which the radicular system develops. In this interval, the application of watering is not required. The need for water rises after the formation of the 4th and 5th leaves, recording the maximum in the period of formation of the floral organs, flowering and formation of pods. The studies aimed at the water consumption and its sources of coating in the cowpea (Table 2) in the conditions of the sandy soils have highlighted the drought resistance of the cowpeas compared to soybeans. The results obtained show that the cowpea provides $4 \%$ from the soil reserve, $60 \%$ from rainfall and $36 \%$ from irrigation, compared to soybeans that provide the largest amount from irrigation water (60\%).

Table 2. Water consumption and supplying sources to some plant species cultivated on sandy soils

\begin{tabular}{|c|c|c|c|c|c|c|c|c|}
\hline \multirow{3}{*}{ Culture } & \multirow{3}{*}{$\begin{array}{c}\text { Average } \\
\text { production } \\
\text { (kg/ha) }\end{array}$} & \multirow{3}{*}{$\begin{array}{c}\text { Water } \\
\text { consumpti } \\
\text { on } \\
\left(m^{3} / h a\right)\end{array}$} & \multicolumn{6}{|c|}{ Sources of coverage } \\
\hline & & & \multicolumn{2}{|c|}{ Soil reserve } & \multicolumn{2}{|c|}{ Rainfall } & \multicolumn{2}{|c|}{ Irrigation } \\
\hline & & & $\%$ & $\mathrm{~m}^{3} / \mathrm{ha}$ & $\%$ & $\mathrm{~m}^{3} / \mathrm{ha}$ & $\%$ & $\mathrm{~m}^{3} / \mathrm{ha}$ \\
\hline Cowpea & 2570 & 4160 & 4 & 160 & 60 & 2500 & 36 & 1500 \\
\hline Soybean & 3020 & 7340 & 6 & 450 & 34 & 2500 & 60 & 4480 \\
\hline
\end{tabular}

The results obtained on sandy soils, showed that the minimum soil humidity ceiling, were we must intervene with irrigation for the cowpea is at $1 / 3$ in the range of humidity accessible on the depth of $50 \mathrm{~cm}$, compared to soybeans in which the application of the irrigation is made at minimum ceiling of water of $2 / 3$ in the range of humidity accessible on the depth of $50 \mathrm{~cm}[6]$. .

Starting from these studies and in order to ensure optimum water consumption of the cowpea plant, soil samples were harvested on the 25th day of each month from April to July, to determine the soil humidity on different depths $(0-125 \mathrm{~cm})$, and in function of the results to determine the amount of water supplemented by irrigation. The results achieved, underlined the existence of two moments with moisture deficiency during the vegetation period of the cowpea (Tables 3, 4).

The first moisture deficiency compared to the field capacity was recorded during the preparation of the germinal bed (25 April) at the level of $-203-49 \mathrm{~m}^{3}$ water/ha, when the water supply of water in the soil $\left(-20.2 \mathrm{~m}^{3}\right.$ water/ha) was lower than the minimum ceiling of water in the soil, on $0-25 \mathrm{~cm}$ soil profile in which the seeds of cowpea germinate and the young plant develops. This moisture deficiency was accentuated in the period following the planting of the varieties of cowpea (27 April), when for a period of 10 days there were no precipitation, it was necessary to apply an emergence watering of $250 \mathrm{~m}^{3}$ water/ha. During the branching phases of the plant and the initiation of the generative organs water consumption was ensured from the recorded rainfall. 


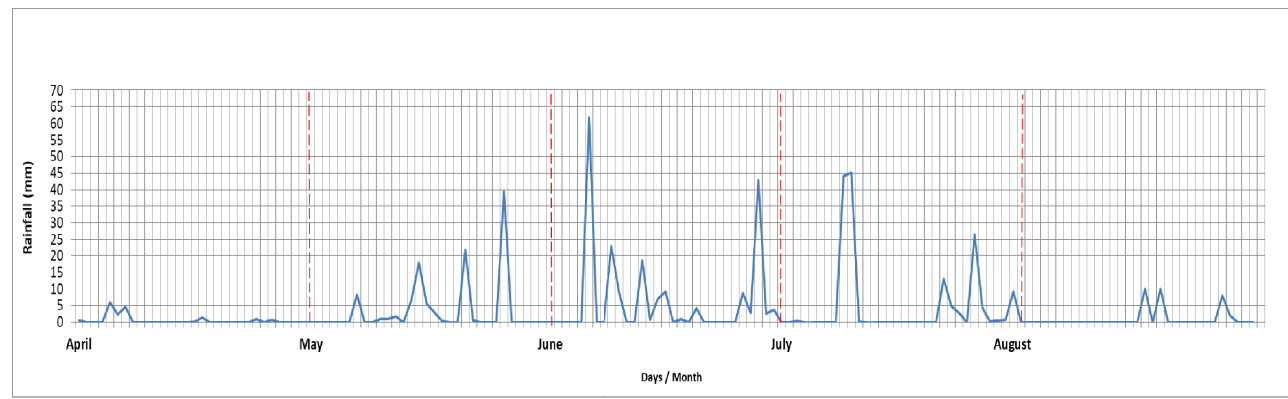

Fig. 1. Evolution of daily rainfall recorded from April to August 2018

Table 3. The evolution of some hydrophysic indices of soil (momental supply, deficit versus capacity field) on the soil profile during the water consumption period of the cowpea plant

\begin{tabular}{|c|c|c|c|c|c|c|c|c|}
\hline \multirow[b]{2}{*}{$\begin{array}{l}\text { The } \\
\text { dept } \\
\text { h of } \\
\text { the } \\
\text { soil } \\
(\mathrm{cm})\end{array}$} & \multicolumn{2}{|c|}{25 April } & \multicolumn{2}{|c|}{25 May } & \multicolumn{2}{|c|}{25 June } & \multicolumn{2}{|c|}{25 July } \\
\hline & $\begin{array}{c}\text { Water } \\
\text { moment } \\
\quad \text { al } \\
\text { supply } \\
\left(\mathrm{m}^{3} / \mathrm{ha}\right)\end{array}$ & $\begin{array}{c}\text { Water } \\
\text { deficit } \\
\text { versus } \\
\text { field } \\
\text { capacit } \\
y \\
\left(\mathrm{~m}^{3} / \mathrm{ha}\right)\end{array}$ & $\begin{array}{c}\text { Water } \\
\text { moment } \\
\text { al } \\
\text { supply } \\
\left(\mathrm{m}^{3} / \mathrm{ha}\right)\end{array}$ & $\begin{array}{c}\text { Water } \\
\text { deficit } \\
\text { versus } \\
\text { field } \\
\text { capacit } \\
y \\
\left(\mathrm{~m}^{3} / \mathrm{ha}\right)\end{array}$ & $\begin{array}{c}\text { Water } \\
\text { momenta } \\
\text { l supply } \\
\left(\mathrm{m}^{3} / \mathrm{ha}\right)\end{array}$ & $\begin{array}{c}\text { Water } \\
\text { deficit } \\
\text { versus } \\
\text { field } \\
\text { capacity } \\
\left(\mathrm{m}^{3} / \mathrm{ha}\right)\end{array}$ & $\begin{array}{c}\text { Water } \\
\text { momen } \\
\text { tal } \\
\text { supply } \\
\left(\mathrm{m}^{3} / \mathrm{ha}\right)\end{array}$ & $\begin{array}{c}\text { Water } \\
\text { deficit } \\
\text { versus } \\
\text { field } \\
\text { capacity } \\
\left(\mathrm{m}^{3} / \mathrm{ha}\right)\end{array}$ \\
\hline $0-25$ & 165 & -203 & 393 & 44 & 263.6 & -34.4 & 545 & 239 \\
\hline $\begin{array}{l}25- \\
50\end{array}$ & 158 & -217 & 410 & 59 & 224.2 & -59.8 & 487 & 178 \\
\hline $\begin{array}{l}50- \\
75\end{array}$ & 216 & -162 & 423 & 76 & 233.6 & -45.4 & 553 & 240 \\
\hline $\begin{array}{l}75- \\
100\end{array}$ & 347 & 2 & 429 & 93 & 212.5 & -65.5 & 444 & 130 \\
\hline $\begin{array}{l}100- \\
125\end{array}$ & 391 & 49 & 465 & 141 & 228.7 & -47.3 & 442 & 127 \\
\hline
\end{tabular}

Starting with the stage of the emergence of florals - flowering (16-25 June) the water consumption of the plant has increased, and the water resources existing in the soil have been insufficient, because over a period of 10 days were registered only $14.4 \mathrm{~mm}$ (Figure 1), the plants of cowpeas beeing exposed to the thermic and hydric stress specific to sandy soils. The humidity determinations carried out on June 25 th (plant reproductive phase) on the soil profile $0-125 \mathrm{~cm}$, revealed a moisture deficiency versus the field capacity contained within the limits-65,6...-34.4 $\mathrm{m}^{3}$ water/ha (Table 3 ).

The water supply in the soil, calculated on the depth of $50 \mathrm{~cm}$ in this phase was less than $163.4 \mathrm{~m}^{3}$ water/ha than the minimum moisture limit of the soil (Table 4), it is necessary to complement the water deficit by irrigation for the purpose of normal conduct of the metabolism of the plant.

The results achieved by in South Africa showed that the reproductive stage is most susceptible to water scarcity, resulting in a reduction of at least $50 \%$ of the efficiency of water use and seed production [3]. Research carried out in France by F. Monteiro De Paula and colab [4], showed that in the case of a moderate shortage of water, the content of lipid in the leaf decreased to the varieties of susceptible cowpea and increased for the resistant ones. At severe stress, the lipid content has been drastically reduced for both susceptible and resistant varieties. Studies in Senegal have highlighted the implication of moisture 
deficiency over the quality of the plant and have shown that water deficiency in the flowering phase has significantly decreased the starch content of the leaf, the number seeds in the pod and the number of pods per plant [7]. The same study shows that cawpea varieties with better drought tolerance are less affected by water shortages compared to sensitive varieties. Most of the areas where the cowpea are grown are prone to drought and it is necessary to solve this problem, because water scarcity becomes a major concern in agriculture.

Table 4. Development of hydrophysic indices of soil (minimum limit, water supply in soil) on the soil profile during the water consumption period of the cowpea plant

\begin{tabular}{|c|c|c|c|c|c|c|c|c|}
\hline \multirow[b]{2}{*}{$\begin{array}{l}\text { The } \\
\text { depth of } \\
\text { the soil } \\
\text { (cm) }\end{array}$} & \multicolumn{2}{|c|}{25 April } & \multicolumn{2}{|c|}{25 May } & \multicolumn{2}{|c|}{25 June } & \multicolumn{2}{|c|}{25 July } \\
\hline & $\begin{array}{l}\text { Minimum } \\
\text { ceiling } \\
\text { of } \\
\text { water } \\
\left(\mathrm{m}^{3} / \mathrm{ha}\right)\end{array}$ & $\begin{array}{l}\text { Water } \\
\text { supply } \\
\text { in soil } \\
\left(\mathrm{m}^{3} / \mathrm{ha}\right)\end{array}$ & $\begin{array}{c}\text { Minim } \\
\text { um } \\
\text { ceiling } \\
\text { of } \\
\text { water } \\
\left(\mathrm{m}^{3} / \mathrm{ha}\right)\end{array}$ & $\begin{array}{c}\text { Water } \\
\text { supply } \\
\text { in soil } \\
\left(\mathrm{m}^{3} / \mathrm{ha}\right. \\
)\end{array}$ & $\begin{array}{c}\text { Minim } \\
\text { um } \\
\text { ceiling } \\
\text { of } \\
\text { water } \\
\left(\mathrm{m}^{3} / \mathrm{ha}\right. \\
)\end{array}$ & $\begin{array}{c}\text { Water } \\
\text { supply } \\
\text { in soil } \\
\left(\mathrm{m}^{3} / \mathrm{ha}\right. \\
\quad)\end{array}$ & $\begin{array}{c}\text { Minim } \\
\text { um } \\
\text { ceiling } \\
\text { of } \\
\text { water } \\
\left(\mathrm{m}^{3} / \mathrm{ha}\right. \\
)\end{array}$ & $\begin{array}{c}\text { Water } \\
\text { supply } \\
\text { in soil } \\
\left(\mathrm{m}^{3} / \mathrm{ha}\right. \\
\quad)\end{array}$ \\
\hline $0-25$ & 185.2 & -20.2 & 181 & 212 & 164.67 & 98.93 & 149.5 & 196.88 \\
\hline $25-50$ & 189.87 & -31.87 & 182.33 & 227.67 & 160.93 & 63.27 & 151.67 & 210.23 \\
\hline $50-75$ & 191.33 & 24.67 & 182.33 & 240.67 & 158.2 & 75.4 & 153.83 & 242.35 \\
\hline $75-100$ & 178 & 169 & 177.33 & 251.67 & 157 & 55.5 & 156 & 256.92 \\
\hline $100-125$ & 178.53 & 212.47 & 177.33 & 287.67 & 157.47 & 71.23 & 157.5 & 274.86 \\
\hline
\end{tabular}

The growth and development of plants and implicitly their production in a particular area, constitute the result of the complex interaction between climatic factors and edafic factors. In this interaction of the existing factors in the area of the sandy soils of Southern Oltenia, the cowpea harnessis with good results the biological potential of the area, due to drought resistance and reduced claims towards the natural fertility of the soil [12]. The drought resistance of the cowpea is given both by the very powerful root system, with a high absorption power, the waxy layer on the leaves, and the number of stomata in the leaf that ranges between $280-327$ stomata $/ \mathrm{mm}^{2}$ on the upper face. The closure of the stomates is a common strategy used by different genotypes of cowpea to avoid dehydration of the foliar apparatus, and the genotypic variance in the conductance of the stomates increases considerably in drought conditions.

In order to assess the use of thermic and hydric stress conditions in the year 2018, the physiological behavior of 4 varieties of cowpea in the flowering phenophyasis of plants was analysed. The results obtained, on the forms of water in the plant and the dry matter content, underlined a different behaviour of the genotypes, depending on the structural particularities of the foliar apparatus and the climatic conditions currently present (Table 5).

Table 5. The dry matter content and the forms of water recorded in the cowpea plants (flowering phase)

\begin{tabular}{|l|c|c|c|c|}
\hline \multicolumn{1}{|c|}{ Genotype } & Dry substance (\%) & $\begin{array}{c}\text { Total water } \\
(\%)\end{array}$ & Free water (\%) & $\begin{array}{c}\text { Linked } \\
\text { water (\%) }\end{array}$ \\
\hline Jiana & 21.31 & 78.69 & 75.40 & 3.29 \\
\hline Aura 26 & 15.44 & 84.56 & 81.61 & 2.95 \\
\hline Ofelia & 17.85 & 82.15 & 79.46 & 2.69 \\
\hline Doljana & 18.43 & 81.57 & 79.43 & 2.14 \\
\hline
\end{tabular}


Thus, the dry substance in the leaves varied in the range between $15.44-21.31 \%$, noting that the maximum value was reached by the Jiana variety. The percentage values of total plant water were between $78.69 \%$ (in the Jiana variety) and $84.56 \%$ (in the Aura 26 variety). The free water recorded the highest values in the Aura 26 variety (81.61\%), and the lowest in the Jiana variety (75.40\%). Under the appearance of linked water from the leaves, an indicator emphasising drought resistance, it was highlighted by a good behavior at drought for the Jiana variety, at which the highest percentage of linked water was recorded. The speciality literature mentions that under unfavourable environmental conditions, when the vital activity of the plant is reduced, the amount of free water decreases, and that of the linked water increases, which causes greater resistance of plants to drought [9]. The higher the amount of linked water in comparance to the free water, the cells are better resistant to high temperatures [11]. The authors underline that the drought resistance of cowpea is due to the properties of cell protoplasm that allows the preservation of the plants life during drought and the resumption of vital processes, with increased intensity, when the soil is supplied with water again. The stress tolerance of the cowpea depends on the genotype and the thermic and hydric regime, and it was determined in the flowering phase of the plant by physiological determinations on the transpiration and photosynthesis of the plant. The obtained results revealed a diurnal variation in the physiological processes in the plant, depending on the variety and climatic conditions (Figure 2). The maximum rate of photosynthesis $\left(37.69 \mu \mathrm{mol} \mathrm{CO} / \mathrm{m}^{2} / \mathrm{s}\right)$ was performed by the Doljana variety at 9 o'clock, when it was on average $30.5{ }^{\circ} \mathrm{C}$ at the leaf level, and the active radiation in photosynthesis was $1560 \mu \mathrm{mol} / \mathrm{m}^{2} / \mathrm{s}$. The increase in temperature and active radiation level in photosynthesis resulted in a reduction in the intensity of the plant photosynthesis. Determinations regarding the rate of transpiration of the plant have highlighted a positive correlation with the temperature at the leaf level. The values of the foliar transpiration oscillated between 2.23-4.86 $\mathrm{mmol} \mathrm{H}_{2} \mathrm{O} / \mathrm{m}^{2} / \mathrm{s}$ at 9 o'clock, when the temperature at leaf level was $30.5{ }^{0} \mathrm{C}$, between $5.39-6.38 \mathrm{mmol} \mathrm{H}_{2} \mathrm{O} / \mathrm{m}^{2} / \mathrm{s}$ at 12 o'clock, when the leaf temperature was $33.41{ }^{0} \mathrm{C}$ and between $4.05-5.23 \mathrm{mmol} \mathrm{H}_{2} \mathrm{O} / \mathrm{m}^{2} / \mathrm{s}$ at 15 o'clock, when the temperature at the leaf level was $33.3{ }^{\circ} \mathrm{C}$ (Figure 2).

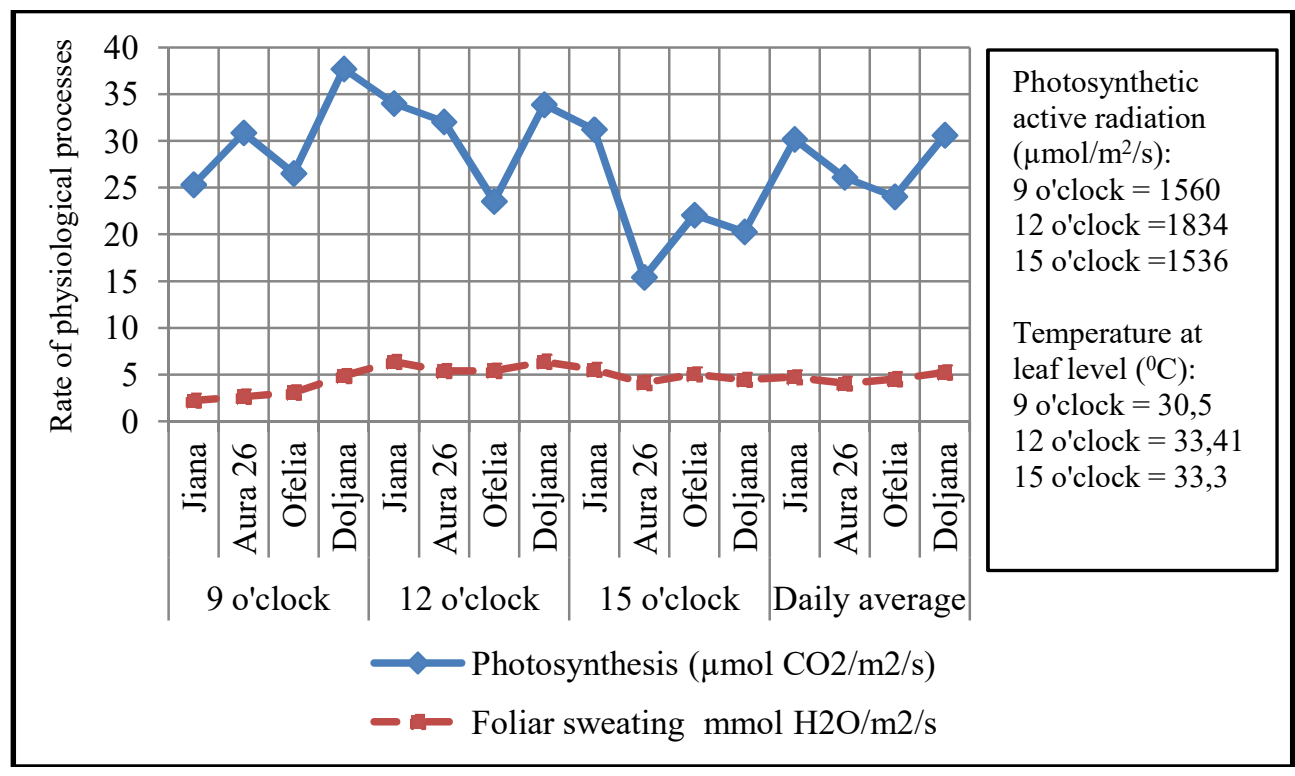

Fig. 2. The diurnal variation of physiological processes in the cowpea according to genotype 
The Varieties Jiana and Doljana, although they recorded high values of the transpiration of the plant, best exploited the water lost by transpiration, as a result of the accumulation of high average values of $\mathrm{CO}_{2}$ through the photosynthesis process $\left(30.17-30.6 \mu \mathrm{mol} / \mathrm{m}^{2} \mathrm{~s}\right)$. The daily average of the transpiration of the plant in the 4 cowpea genotypes, determined in the flowering phase, highlighted values ranging from 4.05 to $5.23 \mathrm{mmol} \mathrm{H}_{2} \mathrm{O} / \mathrm{m}^{2} / \mathrm{s}$, which correlates negatively to the level of the grain production (Table 6).

Table 6. Biological qualities in some varieties of cowpea studied in the conditions of sandy soils in Romania

\begin{tabular}{|c|c|c|c|c|c|c|c|c|}
\hline \multirow[t]{2}{*}{ Variety } & \multicolumn{2}{|c|}{$\begin{array}{l}\text { Plant vegetation } \\
\text { period }\end{array}$} & \multirow{2}{*}{$\begin{array}{l}\text { Plants } \\
\text { height } \\
(\mathrm{cm})\end{array}$} & \multirow[t]{2}{*}{$\begin{array}{l}\text { Foliar } \\
\text { Index }\end{array}$} & \multirow{2}{*}{$\begin{array}{c}\text { Photosynth } \\
\text { esis rate } \\
\left(\mu \mathrm{mol} / \mathrm{m}^{2} / \mathrm{s}\right)\end{array}$} & \multirow{2}{*}{$\begin{array}{c}\text { Foliar } \\
\text { sweating } \\
\text { mmol } \\
\mathrm{H}_{2} \mathrm{O} / \mathrm{m}^{2} / \mathrm{s}\end{array}$} & \multirow{2}{*}{$\begin{array}{l}\text { No. } \\
\text { pods } \\
/ \\
\text { Plant }\end{array}$} & \multirow{2}{*}{$\begin{array}{l}\text { Produc } \\
\text { tion of } \\
\text { grains } \\
\mathrm{kg} / \mathrm{ha}\end{array}$} \\
\hline & No. day & $\sum^{0} \mathrm{C}$ & & & & & & \\
\hline Jiana & 115 & 2648.5 & 140.6 & 7.25 & 30.17 & 4.71 & 6 & 1273.8 \\
\hline Aura 26 & 103 & 2354.5 & 100 & 5.9 & 26.1 & 4.05 & 13 & 2194.4 \\
\hline Ofelia & 102 & 2329.8 & 112 & 6.05 & 24.03 & 4.51 & 11.2 & 2309.5 \\
\hline Doljana & 101 & 2336 & 105 & 6.72 & 30.6 & 5.23 & 10.4 & 1718.2 \\
\hline \multicolumn{4}{|c|}{$\begin{array}{l}\text { Correlation between the foliar index and } \\
\text { the photosynthesis rate of the plant }\end{array}$} & \multicolumn{5}{|c|}{$\begin{array}{l}Y=-3.7012 x^{2}+52.942 x-158.84 ; R^{2}=0.7846 \\
r=0.885\end{array}$} \\
\hline \multicolumn{4}{|c|}{$\begin{array}{l}\text { Correlation between foliar index and } \\
\text { grain production }\end{array}$} & \multicolumn{5}{|c|}{$Y=-744.7 x+6699.7 r=-0.980 *$} \\
\hline \multicolumn{4}{|c|}{$\begin{array}{l}\text { Correlation between the number of } \\
\text { pods/plants and the production of grains }\end{array}$} & \multicolumn{5}{|c|}{$\begin{array}{l}Y=-4.4609 x^{2}+226.81 x+61.039 ; R^{2}=0.8173 \\
r=0.904\end{array}$} \\
\hline \multicolumn{4}{|c|}{$\begin{array}{l}\text { Correlation between foliar sweating and } \\
\text { the production of grains }\end{array}$} & \multicolumn{5}{|c|}{$\mathrm{Y}=-529.34 \mathrm{x}+4322.2 ; \mathrm{r}=-0.544$} \\
\hline
\end{tabular}

The drought tolerance of plants is a genetic feature and is highlighted by the drought index, which represents the ratio of the yields obtained on the supplied and unprocessed parcels of water. The value of this indicator varies depending on the genotype between 0.22 and 0.9 [8] The results obtained from the cowpea culture revealed the differentiation of morphological and productive qualities by genotype (Table 6). The vegetation period of the cowpea genotypes was between 101-115 days, with positive correlation with the thermal resources accumulated during this interval of each variety. In the study conditions, the leaf area index (L.A.I.) in the four varieties of cowpea presented values ranging from the range 5.9-7,25. It was noted by the high values of the L.A.I. varieties Jiana and Doljana, which also recorded a high intensity of the photosynthesis process. The analysis of the production of grains obtained at harvest reveals with the best results $(2194.4-2309.5 \mathrm{~kg} / \mathrm{ha})$ the varieties Aura 26 and Ofelia and underlines positive correlation with the number of pods/plants and negatives with the index of the foliar surface and the rate of foliar sweating.

\section{Conclusions}

1. The culture of cowpea has successfully exploited the thermic and hydric stress of southern Oltenia.

2. During the preparation of the germinating bed for cowpea sowing ( 25 April), the first humidity deficit was recorded in relation to the field capacity at the level of -203-49 $\mathrm{m}^{3}$ water/ha, registering on the soil profile $0-25 \mathrm{~cm}$ a reserve of water in the soil $20.2 \mathrm{~m}^{3}$ water/ha, reserve less than the minimum moisture level in the soil.

3. In the maximum consumption phase of the cowpea plant (plant reproductive phase) a moisture deficiency has been determined against the capacity of the field contained within the limits $-65,6 \ldots-34.4 \mathrm{~m} 3$ water/ha. 
4. In the reproduction phase of the plant the water supply from the soil on the depth of 50 $\mathrm{cm}$ was less than $163.4 \mathrm{~m}^{3}$ water/ha versus the minimum moisture level of the soil, which led to the completion of water deficit by irrigation, for the purpose of normal performance of plant metabolism.

5. The results obtained revealed a diurnal variation in the physiological processes in the plant, depending on the variety and climatic conditions

6. The analysis of the production of grains obtained at harvest reveals the best results (2194,4-2309,5 kg/ha) in the Aura 26 and Ofelia cowpea varieties.

7. The production of grains obtained from the varieties of cowpea has been positively correlated with the number of pods/plants and negative with the index of the foliar surface and the rate of foliar sweating.

\section{Acknowledgement}

This work was supported by a grant of the Romanian Ministery of Research and Innovation CCDI - UEFISCDI, Project INNOVATIVE TECHNOLOGIES FOR IRRIGATION OF AGRICULTURAL CROPS IN ARID, SEMIARID AND SUBHUMID-DRY CLIMATE, project number PN-III-P1-1.2-PCCDI-2017-0254, Contract no. 27PCCDI / 2018, within PNCDI III.

\section{References}

1. A. Zăvoi, Contributions on biology, improvement and agrotechnique of cowpea Vigna sinensis (Torn) Endl. PhD Thesis, Cluj (1967).

2. C. Egashira, T. Yamauchi, Y. Miyamoto, T. Yuasa, Y. Ishibashi, M. Iwaya-Inoue, Physiological Responses of Cowpea (Vigna unguiculata (L.) Walp) to Drought Stress during the Pod-filling Stage. Cryobiology and Cryotechnology, vol. 62, no. 1, pp. 69-75, 2016, Japan (2016)

3. F. E. Ahmed, A. S. H. Suliman, Effect of water stress applied at different stages of growth on seed yield and water-use efficiency of cowpea. Agriculture and Biology Journal of North America, ISSN : 2151-7517, vol.1, No.4, p.534-540, (2010)

4. F. Monteiro De Paula, A.T. PhamThi, J.Vieira De Silva, A.M. Justin, C. Demandre, P. Mazliak, Effects of water stress on the molecular species composition of polar lipids from Vigna unguiculata L. Leaves. Plant Science, Vol. 66, Issue 2, https://doi.org/10.1016/0168-9452(90)90203-Z, France, pp. 185-193, (1990).

5. Gh. Eliade, I. Ghinea, Gh. Ștefanic, Soil microbiology. Ed. Ceres, Bucharest (1975)

6. Gh. Marinică, 1994. Research on the irrigation regime for cowpea (Vigna sinensis), cultivated on the sandy lands of southern Olteniei. Workers. Sc. SCCCPN Dabuleni, vol. 8, pp.43-53, (1994).

7. H. Falalou, Z. Gérard, G. Sita, D. Omar, N.D. Ndèye, B. Serge, Physiological, biochemical and agromorphological responses of five cowpea genotypes (Vigna unguiculata (L.) Walp.) to water deficit under glasshouse conditions, Biotechnol. Agron. Soc. Environ, Base, vol. 11, pp. 225-234, Senegal (2007).

8. I. Burzo, Climate change and effects on horticultural plants, Ed. Sitech, Craiova, pp. 42-91, (2014).

9. I. Burzo, A. Dobrescu, Thermodynamic stress on plants - High temperature and drought-, Ed Ceres, Bucharest, pp.28-50, (2011).

10. O. Düzdemir, A. Ünlükara, A. Kurunç, Response of cowpea (Vigna unguiculata) to salinity and irrigation regimes. New Zealand Journal of Crop and Horticultural Science. ISSN: 0114-0671 (Print) 1175-8783 (Online), vol. 37:3, DOI: 10.1080/01140670909510273, pp. 271-280, Turkey, (2010). 
11. R. B., Dadson, F. M. Hashem, I. Javaid, J. Joshi, A. L Allen, T. E Devine, Effect of Water Stress on the Yield of Cowpea (Vigna unguiculata L. Walp.) Genotypes in the Delmarva Region of the United States. Journal of Agronomy and Crop Science, vol. 191, pp: 210-217. doi: 10.1111/j.1439-037X.2005.00155.x, USA, (2005).

12. R. Drăghici, Contributions to the establishment of the cultivation technology of the cowpea Vigna unguiculata (L.) Walp on the irrigate sands of southern Olteniei. Doctoral Thesis. University of Craiova (1999)

13. R. Draghici, Cowpea - the plant of sandy soils. Ed. Sitech, Craiova, ISBN 978606-11-6587-2, (2018).

14. R. Draghici, I. Draghici, A. Diaconu, M. Croitoru, M. Dima, Significant progress achieved in cowpea breeding in Romania. www.nordsci.org/proceeding2018, ISBN 2603-4107, ISSN 978-619-7495-01-0, DOI 10.32008/B2/V1/34, pp. 321-328, (2018).

15. R. J. Donohue, M. L. Roderick, T. R. McVicar, G. D. Farquhar, Impact of $\mathrm{CO}_{2}$ fertilization on maximum foliage cover across the globe's warm, arid environments. Geophysical Research Letters, vol. 40, http://dx.doi.org/10.1002/grl.50563, Australia, pp 3031-3035, (2013)

16. R. Rivas, H.M. Falcão, R.V. Ribeiro, E.C. Machado, C. Pimentel, M.G. Santos, Drought tolerance in cowpea species is driven by less sensitivity of leaf gas exchange to water deficit and rapid recovery of photosynthesis after rehydration. South African Journal of Botany, vol. 103, pp. 101-107, (2016). 